\title{
ANALISIS YURIDIS KEBERADAAN PERUSAHAAN OUTSOURCING DAN HAK PEKERJA TERKAIT SISTEM KONTRAK BERDASARKAN UNDANG-UNDANG NOMOR 13 TAHUN 2003
}

\section{JURIDICAL ANALYSIS BETWEEN OUTSOURCING COMPANIES AND WORKER'S RIGHTS RELATED TO THE SYSTEM CONTRACT UNDER THE LAW NUMBER 13 OF 2003}

\author{
Haerudin, Endeh Suhartini, \\ dan Edy Santoso
}

\author{
Magister Hukum Sekolah Pascasarjana, \\ Universitas Djuanda Bogor. \\ Korespondensi : Haerudin, Telp. \\ e-mail : haerudin@mum.id
}

Jurnal Living Law, Vol. 13, No.

1, 2021

hlm. 20-34

\begin{abstract}
The purpose of this study are: 1) To find out and analyze the existence of outsourcing companies in contract system workers. To find out and analyze the granting of rights for workers related to the contract system based on Law No. 13 of 2003 concerning Labor. The research method used in this study is a normative juridical study that takes a qualitative approach that looks at and analyzes the legal norms in existing legislation and sociological research as supplementary data as primary data. The results of this study are: 1) The existence of outsourcing companies in contra system workers, in terms of employment relations between workers and outsourcing companies is based on a Specific Time Work Agreement, then the work agreement must require the transfer of the protection of the rights of workers whose objects of work remain, even though there is a change of companies that carry out part of the work of other companies or companies providing workers' services. 2) The granting of rights for workers related to the contract system based on Law Number 13 of 2003, there are still outsourced workers who are not registered with Jamsostek, so the legal protection of health and safety for outsourced workers is not implemented.
\end{abstract}

Keywords : Labor Law; Outsourcing Company; Work Agreement. 


\section{PENDAHULUAN}

Perkembangan di bidang ekonomi semakin maju dengan adanya globalisasi di berbagai sektor, maka timbullah industri-industri perusahaan di Indonesia semakin meningkat, baik perusahaan nasional maupun asing. Dengan meningkatnya dunia industri usaha menuntut persaingan usaha yang sangat ketat saat ini, maka perusahaan dituntut untuk berusaha meningkatkan kinerja usahanya melalui pengelolaan organisasi yang efektif dan efisien.

Agar tujuan-tujuan mereka dapat tercapai maka perusahaan hanya akan memfokuskan diri pada apa yang menjadi kegiatan utama atau bisnis inti mereka, sedangkan

proses perekrutan, penyeleksian, dan pengadaan tenaga kerja diserahkan kepada pihak ketiga. Hal semacam itulah yang dinamakan dengan istilah alih daya (outsourcing).

Negara Indonesia seharusnya jangan ketinggalan dari negara-negara yang dari sisi regulasi dan kualitas Sumber Daya Manusia (SDM) telah siap. Negara India misalnya telah menerima limpahan bisnis alih daya dari perusahaan-perusahaan besar seperti Amerika di bidang informasi teknologi. ${ }^{1}$

Alih daya (outsourcing) sendiri merupakan penyerahan pekerjaan tertentu suatu perusahaan kepada pihak ketiga yang dilakukan dengan tujuan untuk membagi resiko dan mengurangi beban perusahaan tersebut.

Dengan melakukan alih daya ini perusahaan akan menjadi lebih fleksibel, lebih dinamis, dan lebih baik. Perusahaan dapat melakukan perubahan dengan cepat untuk memenuhi perubahan kesempatan sesuai kondisi yang ada.

Namun dalam pelaksanaan sistem alih daya ini masih dianggap oleh tenaga kerja sebagai sistem yang kurang adil di mana tidak adanya kepastian kelangsungan kerja

1 Eko Richardus Indrajit dan Richardus Djokopranoto, Manajemen Outsourcing, Jakarta: Grasindo, 2003, Hlm. 12. bagi tenaga kerja dengan sistem ini. Selain itu dalam sistem alih daya masih dianggap rawan sekali terjadinya penyimpangan dengan melanggar hak asasi manusia tenaga kerja.

Untuk mencegah adanya pelanggaran hak asasi manusia dalam sistem alih daya ini pemerintah memberikan perlindungan hukum terhadap para tenaga kerja dengan sistem alih daya (kontrak).

Hukum ketenagakerjaan adalah himpunan peraturan, baik tertulis maupun tidak tertulis, yang berkenaan dengan suatu kejadian di mana seseorang bekerja pada orang lain, dengan menerima upah. Bahwa dari pengertian tersebut hukum ketenagakerjaan masih belum menyeluruh karena masing-masing definisi belum menjawab permasalahan yang ada dalam hukum ketenagakerjaan karena ruang lingkup masing-masing definisi masih terbatas. ${ }^{2}$

Muhammad Fajrin di sini berpendapat bahwa pentingnya perlindungan bagi pekerja/buruh biasanya berhadapan dengan kepentingan pengusaha untuk tetap dapat bertahan dalam menjalankan usahanya. $^{3}$

Pelaksanaan pembangunan nasional berakibat pada berbagai segi kehidupan berbangsa dan bernegara, terutama berpengaruh pada kehidupan sosial. Sebagaimana telah diamanatkan dalam Alinea Keempat Pembukaan UUD Tahun 1945 bahwa negara bertujuan mewujudkan keadilan sosial dan kesejahteraan umum bagi seluruh rakyat Indonesia. ${ }^{4}$

2 Martin Roestamy dan R. Pepen Rustam Effendi, Perlindungan Hukum Bagi Pekerja Tambang Galian C Dalam Perspektif Pengupahan dan Kesejahteraan Pekerja di Wilayah Provinsi Jawa Barat, Jurnal Living Law, Vol. 10, No. 2, 2018, HIm. 105.

3 Sehat Damanik, Outsourcing dan Perjanjian Kerja, Jakarta: DSS Publishing, 2007, Hlm. 19.

4 Ujang Bahar, Endeh Suhartini, dan Dani Purwanto, Optimalisasi Perlindungan Hukum Tenaga Kerja Dalam Aspek Keselamatan Kerja Pada Proyek Konstruksi di Wilayah Bogor, Jurnal Ilmiah Living Law Volume 12 Nomor 1, Januari 2020, Hlm. 42. 
Sehingga seringkali pihak yang terkait secara langsung adalah pengusaha dan pekerja/buruh. Secara umum persoalan perburuhan lebih banyak diidentikkan dengan persoalan antara pekerja dan pengusaha.

Dalam ajaran Islam perhatian terhadap hak dan perlindungan para pekerja itu hukumnya wajib sesuai hadist nabi dari 'Abdullah bin 'Umar, Nabi shallallahu 'alaihi wa sallam bersabda,

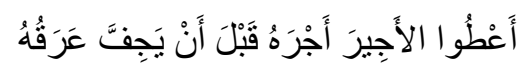

"Berikan kepada seorang pekerja upahnya sebelum keringatnya kering." (HR. Ibnu Majah, shahih). Maksud hadits ini adalah bersegera menunaikan hak si pekerja setelah selesainya pekerjaan.

Memantau perkembangan alih daya (outsourcing) di negara lain adalah di negara lain seperti di India, outsourcing Sumber Daya Manusia (SDM), khususnya yang terkait dengan Teknologi Informasi (IT) paling dominan menjadi solusi ketenagakerjaan dan persoalan SDM di negara tersebut. Bahkan beberapa pebisnis Amerika berminat dan tertarik untuk memindahkan fungsi R\&D tersebut ke India (The Wall Street Daily Journal; 2008,). ${ }^{5}$

Keadaan ini kemudian mendorong munculnya perusahaan penyedia tenaga kerja outsourcing. Perusahaan pemberi kerja hanya menyediakan syarat-syarat atau kriteria yang harus dipenuhi oleh perusahaan outsourcing. Perusahaan outsourcing kemudian menyediakan atau melakukan perekrutan pekerja seperti yang disyaratkan oleh perusahaan pemberi kerja. Pekerja ini nantinya tidak bekerja di tempat perusahaan outsourcing, tetapi ditempat perusahaan pemberi kerja. Dengan demikian, perusahaan yang memerlukan pekerja tidak perlu susah payah mencari, menyeleksi dan melatih pekerja yang dibutuhkan. ${ }^{6}$.

\footnotetext{
The Wall Street Daiy Jornal, 2008.

6 Gunarto Suhardi, Perlindungan Hukum Bagi Pekerja Kontrak, Yogyakarta: Atmajaya, 2006, Hlm. 5.
}

Pasal 65 ayat (8) Undang-Undang Nomor 13 Tahun 2003 tentang Ketenagakerjaan, menyatakan jika perusahaan penyedia tenaga outsourcing tidak mampu memenuhi kewajibannya, maka demi hukum status hubungan kerja antara pekerja dengan perusahaan penyedia tenaga outsourcing berubah menjadi hubungan kerja antara pekerja outsourcing dengan perusahaan pemberi kerja.

Selain itu dalam pelaksanaannya pekerjaan yang di outsourcing tidak hanya sebatas pekerjaan yang tidak berkaitan dengan kegiatan utama tapi termasuk juga pekerjaan yang merupakan kegiatan utama perusahaan tersebut ${ }^{7}$.

Di sini jelas terdapat adanya perbedaan hak antara pekerja/buruh outsourcing dengan pegawai/karyawan tetap, sedangkan dalam peraturan perundangundangan tidak ada pasal dan bab yang membahas masalah kesetaraan hak dan kewajiban antara outsourcing dengan pegawai tetap/yang lainnya yang ada hanya masalah ikatan kerja dan waktu kerja saja, sebenarnya antara outsourcing dengan pegawai tetap/lainnya adalah setara.

Berdasarkan uraian di atas, maka penulis merasa tertarik untuk membahasnya dalam Tesis berjudul Analisis Yuridis Keberadaan Perusahaan Outsourcing Dan Hak Pekerja Terkait Sistem Kontrak Berdasarkan UndangUndang Nomor 13 Tahun 2003.

Berdasarkan latar belakang masalah yang telah diuraikan di atas, peneliti mengidentifikasikan masalah sebagai berikut:

1. Bagaimana keberadaan perusahaan alih daya (outsourcing) dalam pekerja sistem kontrak?

7 Pan Mohamad Faiz, Tinjauan Yuridis terhadap Undang-undang Nomor 13 Tahun 2003 tentang Ketenagakerjaan,

http://jurnalhukum.blogspot.com/2007/05/out sourcing-dan-tenaga-kerja.html., Diakses tanggal 20 Juni 2020. 
2. Bagaimana pemberian hak bagi pekerja terkait sistem kontrak berdasarkan Undang-undang Nomor 13 Tahun 2003 tentang Ketenagakerjaan?

\section{METODE PENELITIAN}

Metode penelitian yang digunakan dalam penelitian ini adalah pendekatan yuridis normatif, yaitu hukum dikonsepsikan sebagai norma, kaidah, asas atau dogma-dogma/yurisprudensi dan pendekatan yuridis empiris yaitu hukum sebagai gejala masyarakat, sebagai institusi sosial atau perilaku yang mempola.

\section{PEMBAHASAN}

\section{A. KEBERADAAN PERUSAHAAN ALIH DAYA (OUTSOURCING) DALAM PEKERJA SISTEM KONTRAK}

Pengertian alih daya (outsourcing) adalah hubungan di mana pekerja/buruh yang dipekerjakan di suatu perusahaan dengan sistem kontrak, tetapi kontrak tersebut bukan diberikan oleh perusahaan pemberi kerja melainkan oleh perusahaan pengerah tenaga kerja ${ }^{8}$ (penyalur tenaga kerja).

Apabila ketentuan-ketentuan yang telah disebutkan di atas tidak terpenuhi, maka demi hukum status hubungan kerja antara pekerja/buruh dan perusahaan penyedia jasa pekerja/buruh beralih menjadi hubungan kerja antara pekerja/buruh dan perusahaan pemberi pekerjaan.

Namun Putusan Mahkamah Konstitusi No. 27/PUU-IX/2011, menyatakan bahwa ada model yang harus dipenuhi dalam perjanjian kerja outsourcing, yaitu: Pertama, dengan mensyaratkan agar perjanjian kerja antara pekerja dan perusahaan yang melaksanakan pekerjaan outsourcing tidak berbentuk Perjanjian Kerja Waktu Tertentu (PKWT), akan tetapi berbentuk Perjanjian Kerja Waktu Tidak Tertentu (PKWTT). Kedua, menerapkan prinsip pengalihan tindakan perlindungan bagi pekerja yang bekerja pada perusahaan yang melaksanakan pekerjaan outsourcing. Putusan Mahkamah Konstitusi ini menyiratkan bahwa setiap pekerja outsourcing terjamin kedudukannya dalam perusahaan pengguna karena perjanjian kerjanya bersifat PKWTT atau tetap. Akan tetapi masalah kemudian timbul secara yuridis, yaitu siapakah sebenarnya para pihak yang mengadakan perjanjian kerja, sebab seperti dikemukakan sebelumnya, perjanjian kerja outsourcing dilakukan antara perusahaan penyedia jasa dengan pekerja ahli daya (outsourcing), di samping sifat dan jenis pekerjaan outsourcing pada dasarnya bukan untuk pekerjaan pokok dan oleh karenanya disubkontrakkan.

Semakin meningkatnya pertumbuhan perusahaan alih daya, dapat dilihat dari berbagai kota di Indonesia di mana perusahaan ini sudah banyak berdiri. Berikut beberapa contoh nama-nama perusahaan yang mengeluarkan tenaga alih daya sebagai berikut:

\begin{tabular}{|c|c|c|}
\hline No. & $\begin{array}{c}\text { NAMA } \\
\text { PERUSAHAMN }\end{array}$ & ALAMAT \\
\hline 1. & $\begin{array}{l}\text { Advanced Career } \\
\text { Indonesia }\end{array}$ & $\begin{array}{lr}\text { Advanced } & \text { Career } \\
\text { Indonesia Jlo Building, } \\
\text { 3rd. Fl Jl Kemang Raya } \\
\text { No. 11 Kemang Jakarta } \\
\text { Selatan } 12730\end{array}$ \\
\hline 2. & $\begin{array}{lr}\text { PT. } & \text { Perdana } \\
\text { Perkasa } & \text { Elastindo }\end{array}$ & $\begin{array}{lr}\text { Advanced } & \text { Career } \\
\text { Indonesia jlo Building, } \\
\text { 3rd Fl Jl Kemang Raya } \\
\text { No. 11 Kemang Jakarta } \\
\text { Selatan } 12730 \\
\end{array}$ \\
\hline 3. & $\begin{array}{ll}\text { PT. } & \text { Dwinara } \\
\text { Perkasa } & \end{array}$ & $\begin{array}{l}\text { JI Pahlawan Kerja No } 29 \\
\text { Pekanbaru - RIAU } 28282\end{array}$ \\
\hline 4 & $\begin{array}{l}\text { Corporate Human } \\
\text { Resource }\end{array}$ & $\begin{array}{l}\text { J1 Pemuda Kav. 79, No. } \\
\text { 10, Rawamangun - } \\
\text { Jakarta Timur } 13220 \text { DKI } \\
\text { Jakarta }\end{array}$ \\
\hline 5 & $\begin{array}{l}\text { FT. Multi Global } \\
\text { Adikarindo }\end{array}$ & $\begin{array}{lr}\text { J1 Raya } & \text { Boulevard } \\
\text { L1/19R - } & \text { Citra Raya } \\
\text { Cikupa }- & \text { Tangerang } \\
15710 \text { Banten } & \\
\end{array}$ \\
\hline
\end{tabular}

${ }^{8}$ Abdul Khakim, Loc.Cit., Hlm. 74. 


\begin{tabular}{|c|c|c|}
\hline 6. & $\begin{array}{l}\text { FT. Buana Elok } \\
\text { Semesta Tentram }\end{array}$ & 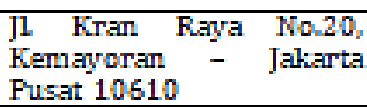 \\
\hline 7. & $\begin{array}{lr}\text { PT. } & \text { Persada } \\
\text { (Personel } & \text { Alih } \\
\text { Daya) } & \end{array}$ & 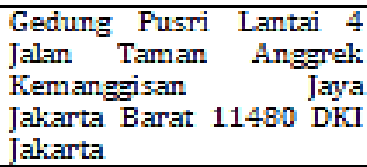 \\
\hline 8. & $\begin{array}{l}\text { FT: Sentinel } \\
\text { Garda Semesta }\end{array}$ & $\begin{array}{l}\text { Perum. Juanda Harapan } \\
\text { Permai Blok I No. 1 } \\
\text { Sidoarjo - Jawa Timur } \\
61254\end{array}$ \\
\hline 9. & $\begin{array}{l}\text { PT. Cipta Inti } \\
\text { Layanan Prima }\end{array}$ & $\begin{array}{lll}\text { J1 Onta } & \text { Baru No. } 50 \\
\text { Makassar } & & \text { Sulawesi } \\
\text { Selatan } & & \\
\end{array}$ \\
\hline 10. & $\begin{array}{l}\text { FT: Bali Citra Tata } \\
\text { Niage }\end{array}$ & $\begin{array}{l}\text { Wisma Bisnis Indonesia, } \\
\text { JL KH Mas Mansyur } \\
\text { No.12A Lt.3 Jakarta Pusat } \\
\text { 10220 DKI Jakarta }\end{array}$ \\
\hline 11. & $\begin{array}{l}\text { FT: Alihdaya } \\
\text { Indonesia }\end{array}$ & $\begin{array}{l}\text { Graha Alihdaya } \text { J1 } \\
\text { Kramat Pela Raya No. } \\
\text { 212, Jakarta } 12140\end{array}$ \\
\hline 12 & $\begin{array}{l}\text { Pundee } \\
\text { Associates }\end{array}$ & $\begin{array}{l}\text { Graha Fharama Prima } \\
\text { 2nd Floor JL. KH. Ahmad } \\
\text { Dahlan No. } 69 \text { A-B } \\
\text { Jakarta Selatan } 12130\end{array}$ \\
\hline
\end{tabular}

Perusahaan yang dijabarkan di atas ini merupakan perusahaan yang memperlengkapi tenaga-tenaga kerja yang kemudian nantinya akan disalurkan kepada pihak perusahaan yang membutuhkan tenaga alih daya sesuai kebutuhan dan keterampilan yang dimiliki tenaga kerja tersebut. Perusahaan-perusahaan yang menggunakan sistem alih daya tentunya memiliki beberapa alasan, yakni: Perusahaan dapat fokus terhadap core business, penghematan biaya turn over karyawan menjadi rendah, modernisasi dunia usaha, adanya efektivitas mindpower, dan lain-lain. ${ }^{9}$

Hak-hak dasar dari pekerja yaitu hak yang diatur dalam peraturan perundangundangan yang disebut dengan hak normatif di antaranya hak untuk mendapatkan upah kerja, hak atas pembayaran bukan upah, hak atas keselamatan dan kesehatan kerja, hak untuk ikut membuat peraturan perusahaan, hak membentuk lembaga kerjasama bipartit, hak sebagai peserta program jaminan sosial, hak mendapatkan kesempatan beribadah, hak atas fasilitas kesejahteraan dan hak atas surat keterangan ${ }^{10}$.

Perjanjian adalah "suatu perbuatan dengan mana satu orang atau lebih

\footnotetext{
${ }^{9}$ Ibid., Hlm. 2.

${ }^{10}$ Lalu Husni, Op.Cit., Hlm. 49.
}

mengikatkan dirinya terhadap satu orang lain atau lebih. Dalam membuat perjanjian, kedudukan antara para pihak yang mengadakan perjanjian sama dan sederajat"11.

Pengusaha dengan pekerja terikat dalam suatu perjanjian kerja yang melandasi adanya hubungan kerja, yang di dalamnya terkandung unsur-unsur:

1) Pekerjaan;

2) Upah;

3) Kewenangan dari pihak pengusaha memberi instruksi, pimpinan, bimbingan kepada pekerja/buruh yang dipekerjakan.

Pekerjaan yang dimaksud adalah yang dijadikan obyek perjanjian kerja. Di dalam Undang-undang No. 13 Tahun 2003 tentang Ketenagakerjaan tidak memberikan definisi tentang pekerjaan, hanya saja ditentukan dalam Pasal 52 ayat (1) huruf d Undang-undang No. 13 Tahun 2003 tentang Ketenagakerjaan ditentukan bahwa: "Pekerjaan yang diperjanjikan tidak bertentangan dengan ketertiban umum, kesusilaan dan peraturan perundang-undangan".

Ketentuan mengenai upah yang diterima oleh pekerja ini merupakan suatu hak yang seharusnya diterima oleh pekerja setelah pekerja menjalankan kewajiban bagi perusahaan yaitu bekerja. Kewenangan dari pihak pengusaha memberi instruksi, pimpinan, bimbingan kepada pekerja/buruh yang dipekerjakan.

Upah sebagai segala penghasilan, yang diterima oleh seorang pekerja, baik berupa uang ataupan barang dalam jangka waktu tertentu pada suatu kegiatan ekonomi. Berdasarkan pengertian ini, yang masuk ke dalam pengertian upah adalah semua bentuk penerimaan yang diterima oleh pekerja, apapun bentuknya ${ }^{12}$.

Membayar upah tepat pada waktunya adalah kewajiban utama dan terpenting

\footnotetext{
11 Syamsuddin, Mohd. Syaufii, Norma Perlindungan Dalam Hubungan Industrial, Jakarta: Sarana Bhakti Persada, 2004, Hlm. 110.

12 Lanny Ramli, Hukum Ketenagakerjaan, Surabaya: Airlangga University Press, 2008, HIm. 241.
} 
bagi pengusaha, dalam suatu ikatan kerja. Mengenai besar, bentuk, atau waktu pembayaran upah diserahkan kepada para pihak untuk mengaturnya sendiri, di dalam perjanjian. Apabila dalam membuat perjanjian kerja upah tidak diperjanjikan, upah diberikan menurut kebiasaan setempat atau dengan memperhatikan keadilan.

Perlindungan hukum terhadap pekerja oursourcing yaitu penghormatan atas hakhaknya di antaranya hak untuk mendapatkan perlakuan yang adil sesuai dengan peraturan perundang-undangan, menjadi penting untuk mencegah kesewenang-wenangan penguasa yang mengatas namakan jabatannya dalam hal ini adalah dinas tenaga kerja sebagai pihak yang melakukan pengawasan tenaga kerja.

Perjanjian kerja sistem outsourcing sangat rentan terhadap masalah yang berakibat terjadinya perselisihan hubungan industrial. Perselisihan hubungan industrial sebagai suatu sebab terjadinya suatu penyelesaian perselisihan hubungan industrial. Penyelesaian hubungan industrial yang selama ini dikenal yaitu penyelesaian secara damai antara kedua belah pihak yaitu pihak pekerja/buruh dengan pengusaha yang dikenal dengan penyelesaian secara bipartit.

Kewenangan Mahkamah Konstitusi untuk melakukan uji materiil Pasal 66 ayat (7) Undang-undang No 13 Tahun 2003 tentang Ketenagakerjaan terhadap ketentuan Pasal 27 Undang-undang Dasar Negara Republik Indonesia Tahun 1945, maka dapat dijelaskan bahwa Mahkamah Konstitusi berwenang dalam putusannya untuk menyatakan bahwa ketentuan Pasal 64 ayat (7) Undang-undang No 13 Tahun 2003 tentang Ketenagakerjaan tidak mempunyai kekuatan hukum. Putusan Mahkamah Konstitusi tersebut mempunyai kekuatan hukum dan tidak ada instansi pembanding dalam arti putusan Mahkamah Konstitusi yang menyatakan Pasal 64 ayat (7) Undang-undang No 13 Tahun 2003 tentang Ketenagakerjaan mempunyai kekuatan hukum untuk dilaksanakan.

Sesuai dengan pengertian di atas berarti yang dimaksud dengan perjanjian outsourching merupakan perjanjian bisnis antara satu perusahaan (dapat juga orang perorangan) dengan perusahaan lain (harus berbadan hukum) untuk suatu kesepakatan bersama mengenai penyerahan sebagian pelaksanaan pekerjaan. Jadi, yang dimaksud dengan pekerja outsourcing adalah pekerja yang bekerja pada suatu perusahaan penyedia jasa pekerja atau perusahaan penerima pemborongan pekerjaan.

\section{B. PEMBERIAN HAK BAGI PEKERJA TERKAIT SISTEM KONTRAK BERDASARKAN UNDANG-UNDANG NOMOR 13 TAHUN 2003 TENTANG KETENAGAKERJAAN}

Pekerja adalah bagian dari rakyat Indonesia yang perlu dilindungi. Prinsip perlindungan hukum bagi rakyat Indonesia adalah prinsip pengakuan dan perlindungan terhadap harkat dan martabat manusia yang bersumber pada negara hukum yang berdasarkan Pancasila.

Perlindungan hukum bagi pekerja didasarkan pada UUD Tahun 1945, yaitu dalam ketentuan Pasal 28 D ayat (1), dan ayat (2). Pasal 28 D ayat (1) UUD Tahun 1945 yang menyatakan bahwa: "Setiap orang berhak atas pengakuan, jaminan, perlindungan dan kepastian hukum yang adil serta perlakuan yang sama di hadapan hukum".

Selanjutnya Pasal 28 D ayat (2) UUD Tahun 1945 menyatakan bahwa "Setiap orang berhak untuk bekerja serta mendapat imbalan dan perlakuan yang adil dan layak dalam hubungan kerja". Ketentuan tersebut, menunjukkan bahwa di Indonesia hak untuk bekerja telah memperoleh tempat yang penting dan dilindungi oleh UUD Tahun 1945. Pengaturan perlindungan hukum bagi pekerja di dalam Undang-undang Nomor 13 Tahun 2003 tentang Ketenagakerjaan 
yaitu diatur dalam Pasal 67 sampai dengan Pasal 101.

Pekerja outsourcing memiliki kepentingan-kepentingan yang telah ditransformasikan ke dalam hak pekerja yang oleh hukum perlu untuk dilindungi oleh pengusaha. Abdul Khakim mengatakan bahwa: "Hakikat hak pekerja merupakan kewajiban pengusaha", dan sebaliknya "hak pengusaha merupakan kewajiban pekerja/buruh". ${ }^{13}$ Perlindungan atas hakhak dasar pekerja yang terjalin dari hubungan kerja merupakan kepentingan pekerja yang harus dipenuhi oleh pengusaha, karena hak-hak tersebut merupakan kebutuhan pekerja sejak mereka beranjak dan menentukan sikap untuk bekerja.

Selanjutnya dalam Pasal 66 ayat (2) huruf c disebutkan bahwa "Perlindungan upah dan kesejahteraan, syarat-syarat kerja, serta perselilsihan yang timbul menjadi tanggung jawab perusahaan penyedia jasa pekerja/buruh".

Kebutuhan-kebutuhan pekerja itulah yang harus dilindungi dan dipenuhi oleh pengusaha. Menurut Djoko Triyanto perlindungan kerja meliputi aspek-aspek yang cukup luas, yaitu perlindungan dari segi fisik yang mencakup perlindungan keselamatan dari kecelakaan kerja dan kesehatannya serta adanya pemeliharaan moril kerja dan perlakuan yang sesuai dengan martabat manusia maupun moral dan agama ${ }^{14}$ sebagai konsekwensi lahirnya hubungan kerja, yang secara umum tertuang dalam Undang-undang No 13 Tahun 2003 tentang Ketenagakerjaan seperti:

a. Hak untuk memperoleh kesempatan dan perlakuan yang sama tanpa diskriminasi (Pasal 5);

b. Hak untuk memperoleh peningkatan dan pengembangan kompetensi serta mengikuti pelatihan (Pasal 11);

13 Abdul Khakim, Op.Cit., Hlm. 126.

14 Djoko Triyanto, Hubungan Kerja di Perusahaan Jasa Konstruksi, Bandung: Mandar Maju, 2004, Hlm.102. c. Hak dan kesempatan yang sama untuk memilih, mendapatkan, atau pindah pekerjaan (Pasal 31);

d. Hak atas Kepastian dalam Hubungan Kerja (Pasal 50 s.d. Pasal 66);

e. Hak atas Waktu Kerja Waktu Istirahat, Cuti, Kerja Lembur dan Upah Kerja Lembur (Pasal 77);

f. Hak berkaitan dengan pengupahan, jaminan sosial dan kesejahteraan (Pasal 88);

g. Hak mendapat perlindungan Keselamatan dan Kesehatan Kerja, moral dan kesusilaan, serta perlakuan yang sesuai dengan harkat dan martabat manusia serta Hak memperoleh jaminan kematian akibat kecelakaan kerja (Pasal 86);

h. Hak berorganisasi dan berserikat (Pasal 104);

i. Hak mogok kerja (Pasal 137);

j. Hak untuk mendapatkan uang pesangon setelah di PHK (Pasal 156).

Hak-hak seperti di atas merupakan hak-hak dasar pekerja yang tidak semuanya diperoleh pekerja/buruh outsourcing. Perlakuan pengusaha yang tidak adil dan layak terhadap pekerja outsourcing menimbulkan kesan negatif terhadap legalitas sistem outsourcing.

Demi menunjang kinerja para pekerja/buruh maka dibuat upaya untuk melindungi keselamatan kerja dan keamanan bagi tenaga kerja/buruh atau biasa dikenal dengan Jaminan Sosial Tenaga Kerja (Jamsostek). Jamsostek diatur di dalam Pasal 99 Undang-undang Nomor 13 Tahun 2003 tentang Ketenagakerjaan yang menyatakan bahwa:

a. Setiap pekerja/buruh dan keluarganya berhak untuk memperoleh jaminan sosial tenaga kerja,

b. Jaminan sosial tenaga kerja sebagaimana dimaksud dalam ayat (1), dilaksanakan sesuai dengan peraturan perundang-undangan yang berlaku.

Dalam hal ini penyelenggara Jamsostek adalah Badan Penyelenggara Jaminan Sosial Tenaga Kerja (BPJS). Program 
jaminan sosial tenaga kerja terdiri dari berikut ini: ${ }^{15}$

a. Jaminan berupa uang yang meliputi:

1) Jaminan Kecelakaan Kerja (JKK)

2) Jaminan Kematian (JK)

3) Jamninan Hari Tua (JHT)

b. Jaminan berupa pelayanan, yaitu Jaminan Pemeliharaan Kesehatan (JPK).

Pelaksanaan BPJS Ketenagakerjaan dalam perusahaan kecil sampai perusahaan menengah, bahkan perusahaan skala besar terkadang terjadi pelanggaran BPJS Ketenagakerjaan disebabkan karena beberapa faktor antara lain, para pekerja/buruh tidak diikutsertakan ke dalam program BPJS Ketenagakerjaan atau apabila diikutsertakan tidak sepenuhnya mematuhi ketentuan hukum.

Berdasarkan ketentuan Pasal 15 ayat (1) Undang-undang Nomor 24 Tahun 2011 tentang Badan Penyelenggara Jamninan Sosial yang menegaskan bahwa "pemberi kerja secara bertahap wajib mendaftarkan dirinya dan pekerjanya sebagai peserta kepada BPJS sesuai dengan program Jaminan Sosial yang diikuti". Kemudian ditegaskan kembali dalam ayat (2) "pemberi kerja, dalam melakukan pendaftaran sebagaimana dimaksud pada ayat (1), wajib memberikan data dirinya dan pekerjanya berikut anggota keluarganya secara lengkap dan benar kepada BPJS". 16

Ketentuan tersebut jelas, bahwa BPJS Ketenagakerjaan tidak membedakan status hubungan kerjanya, baik itu pekerja/buruh tetap, harian lepas, borongan maupun perjanjian kerja waktu tertentu atau besar kecilnya perusahaan, kemudian pembayaran upah BPJS Ketenagakerjaan berdasarkan upah minimum atau upah pokok saja. Pelaksanaan BPJS Ketenagakerjaan di PT. Mitra Utama

15 Hardijan Rusli, Hukum Ketenagakerjaan, Bogor: Ghalia Indonesia Cet. Ke-2, 2011, Hlm. 102.

16 Nuridin dan Tiyas Vika Widyastuti, Pelaksanaan Hak Normatif Tenaga Outsourcing di Perusahaan Penyedia Jasa Pekerja, Brebes: Diya Media Group, 2017, Hlm. 235.
Madani mempunyai 56 pekerja/buruh, tetapi hanya sebanyak 50 pekerja/buruh yang diikutsertakan BPJS Ketenagakerjaan. Pengusaha membayar upah BPJS Ketenagakerjaan berdasarkan upah minimum atau upah pokok saja. Akibatnya, jumlah iuran BPJS Ketenagakerjaan rendah termasuk di dalamnya iuran Jaminan Hari Tua yang diperoleh oleh pekerja/buruh pada saat usia pensiun tiba nilainya sangat kecil. Hal ini jelas merupakan pelanggaran hukum. Persoalannya, kondisi demikian terjadi dengan pembiaran yang berlarutlarut tanpa adanya tindakan dan penegakan hukum oleh pemerintah, di mana merupakan tugas pegawai pengawas ketenagakerjaan. ${ }^{17}$

Perlindungan kerja tersebut akan diuraikan dengan penjelasan sebagai berikut:

1. Perlindungan Norma Keselamatan dan Kesehatan Kerja

Bentuk perlindungan keselamatan dan kesehatan kerja yang diberikan kepada pekerja adalah dengan mengikutsertakan mereka ke dalam program Jamsostek. Secara fisik memang mereka kita pekerjakan, namun secara moral kita mempunyai tanggung jawab. ${ }^{18}$

Tidak semua pekerja terdaftar dalam program Jamsostek. Tergantung dengan nilai kontrak dengan pemberi kerja. Bagi yang tidak diikutsertakan dalam Jamsostek mereka kita kenakan biaya asuransi sebesar Rp.75.000 (tujuh puluh lima ribu rupiah) sampai Rp.150.000 (seratus lima puluh ribu rupiah) setiap tahun". 19

Saya dan keluarga terdaftar dalam Jamsostek. Kalau sakit bisa menggunakan kartu Jamsostek. ${ }^{20}$ Bentuk keselamatan dan kesehatan

17 Ibid, Hlm. 235-236.

18 Hasil wawancara dengan Bapak A, Direktur Utama PT. Mitra Utama Madani, pada tanggal 18 Juni 2020.

19 Ibid.

20 Hasil wawancara dengan Bapak B, pekerja outsourcing PT. Mitra Utama Madani, pada tanggal 19 Juni 2020. 
kerja yang diberikan perusahaan, saya didaftarkan ke dalam Jamsostek. ${ }^{21}$ Perlindungan keselamatan dan kesehatan pekerja saya dapatkan melalui Jamsostek. Saya dan keluarga terdaftar dalam Jamsostek. ${ }^{22}$ Saya belum terdaftar dalam Jamsostek karena persyaratannya belum lengkap. Kendalanya KTP saya belum ada jadi tidak memenuhi syarat. Kalau sakit terpaksa pakai biaya sendiri.23 Saya belum terdaftar dalam Jamsostek karena ada persyaratan yang belum dilengkapi. Kalau misalnya sakit pakai biaya sendiri. ${ }^{24}$

Berdasarkan hasil penelitian di atas, dapat dilihat bahwa bentuk perlindungan keselamatan dan kesehatan kerja yang diberikan oleh PT. Mitra Utama Madani kepada pekerjanya adalah dengan mengikutsertakan pekerjanya ke dalam program Jamsostek. Akan tetapi tidak semua pekerja pada PT. Mitra Utama Madani terdaftar menjadi peserta Jamsostek. Pekerja PT. Mitra Utama Madani yang tidak terdaftar menjadi anggota Jamsostek dikarenakan ada persyaratan yang belum dilengkapi yaitu pekerja tersebut belum memiliki Kartu Tanda Penduduk (KTP). Dalam Undang-undang Jaminan Sosial Tenaga Kerja Pasal 3 ayat (2) dikatakan bahwa: "Setiap tenaga kerja berhak atas jaminan sosial tenaga kerja". Selanjutnya dalam Pasal 17 ditegaskan bahwa: "Pengusaha dan tenaga kerja wajib ikut serta dalam program jaminan sosial tenaga kerja”.

21 Hasil wawancara dengan Bapak C, pekerja outsourcing PT. Mitra Utama Madani, pada tanggal 19 Juni 2020.

22 Hasil wawancara dengan Ibu D, pekerja outsourcing PT. Mitra Utama Madani, pada tanggal 19 Juni 2020.

23 Hasil wawancara dengan Ibu E, pekerja outsourcing PT. Mitra Utama Madani, pada tanggal 19 Juni 2020.

24 Hasil wawancara dengan Ibu F, pekerja outsourcing PT. Mitra Utama Madani, pada tanggal 19 Juni 2020.
Pada PT. Mitra Utama Madani masih ada pekerja outsourcing yang tidak terdaftar dalam Jamsostek, sehingga perlindungan hukum terhadap kesehatan dan keselamatan bagi pekerja outsourcing tersebut tidak terlaksana, karena mereka tidak terlindungi dari resiko yang dapat saja timbul saat melakukan pekerjaan maupun di luar masa pekerjaan.

2. Perlindungan Norma Kerja

Norma kerja meliputi perlindungan terhadap pekerja yang bertalian dengan waktu bekerja, istirahat, cuti kerja, sistem pengupahan dan perjanjian kerja.

a. Waktu Kerja, Istirahat dan Cuti

Waktu kerja yang diterapkan oleh PT. Mitra Utama Madani kepada pekerja outsourcing yang bekerja sebagai security adalah 8 jam dalam 1 hari, dimulai pukul 06.00 WIB s.d 14.00 WIB dan selebaihnya dianggap jam kerja lembur. Jam kerja lembur adalah pukul 14.00 s.d pukul 18.00 WIB. Dalam 1 (satu) minggu pekerja PT. Mitra Utama Madani bekerja selama 6 (enam) hari yaitu hari Senin s.d hari Sabtu. Jadi total jam kerja pekerja outsourcing PT. Mitra Utama Madani yang bekerja sebagai security dalam 1 (satu) minggu adalah 48 (empat puluh delapan) jam.

Jam kerja yang diterapkan oleh PT. Mitra Utama Madani tersebut tidak sesuai dengan ketentuan Undangundang Nomor 13 Tahun 2003 tentang Ketenagakerjaan yang menyatakan bahwa total jam kerja dalam 1 (satu) minggu adalah 40 (empat puluh) jam. Hal ini melanggar Pasal 77 ayat (1) yang mengatur bahwa total jam kerja dalam 1 (satu) minggu tidak boleh lebih dari 40 (empat puluh) yaitu 7 (tujuh) jam 1 (satu) hari dan 40 (empat puluh) jam 1 (satu) minggu untuk 6 (enam) hari kerja dalam 1 (satu) minggu. 
b. Pengupahan

Pada PT. Mitra Utama Madani, upah yang diberikan kepada pekerja outsourcing sudah sesuai dengan Upah Minimum Provinsi.

Upah yang dibayarkan kepada pekerja disesuaikan dengan nilai kontrak dari pemberi kerja. Kita maunya upah yang dibayarkan adalah sesuai dengan UMP. Tapi kalau dalam nilai kontraknya di bawah UMP kita tidak bisa berbuat banyak. Perusahaan outsourcing ini diibaratkan seperti penyampai amanah oleh perusahaan pemberi kerja. Ketika pemberi kerja memberikan upah sesuai nilai kontrak maka itu juga yang kita berikan kepada pekerja. ${ }^{25}$

Sesuai dengan ketentuan dari Disnaker seharusnya THR diberikan kepada pekerja sebesar 1 (satu) bulan gaji, namun itu kembali lagi kepada perusahaan pemberi kerja. Kalau dalam kontrak perusahaan ada mencantumkan THR maka kami akan memberi THR kepada pekerja.

Gaji yang diberikan oleh PT. Mitra Utama Madani sudah sesuai UMP. ${ }^{26}$ Ada waktu kerja lembur dari jam 2 (dua) siang sampai jam 6 (enam) sore. Perusahaan memberikan THR. Kami menerima THR 1 (satu) minggu sebelum lebaran. Gaji yang diberikan oleh PT. Mitra Utama Madani sudah sesuai UMP. ${ }^{27}$ Perusahaan ada menerapkan kerja lembur. Waktu kerja lembur dimulai dari jam 2 siang sampai jam 6 sore. Perusahaan ada memberikan THR. Kami menerima THR 1 (satu) minggu sebelum lebaran. Gaji pokok saya setiap bulannya sudah

25 Hasil wawancara dengan Bapak A, Direktur Utama PT. Mitra Utama Madani, pada tanggal 19 Juni 2020.

26 Hasil wawancara dengan Bapak B, pekerja outsourcing PT. Mitra Utama Madani, pada tanggal 19 Juni 2020.

27 Hasil wawancara dengan Bapak C, pekerja outsourcing PT. Mitra Utama Madani, pada tanggal 19 Juni 2020. sesuai dengan UMP. ${ }^{28}$ Ada kerja lembur yang diberikan perusahaan. Jam Kerja lembur dimulai jam 2 siang sampai jam 6 sore. Perusahaan ada memberikan tunjangan jabatan. Perusahaan ada memberikan THR sebelum hari raya. Gaji yang diberikan oleh PT. Mitra Utama Madani sudah sesuai UMP“.29 Ada waktu kerja lembur dari jam 2 (dua) siang sampai jam 6 (enam) sore. Waktu lebaran perusahaan ada memberikan THR. Gaji yang diberikan oleh PT. Mitra Utama Madani sudah sesuai UMP. ${ }^{30}$ Perusahaan ada menerapkan kerja lembur. Waktu kerja lembur dimulai dari jam 2 siang sampai jam 6 sore. Perusahaan ada memberikan THR sebelum hari raya.

Berdasarkan hasil wawancara di atas, upah yang dibayarkan oleh PT. Mitra Utama Madani kepada pekerja outsourcing sudah sesuai dengan Upah Minimum Provinsi. Kalau upah yang dibayarkan di bawah Upah Minimum Provinsi hal ini melanggar ketentuan Pasal 93 ayat (2) Undang-undang Nomor 13 Tahun 2003 tentang Ketengakerjaan yang menyatakan bahwa pengusaha dilarang membayar upah lebih rendah dari upah minimum.

Berdasarkan ketentuan Undangundang Nomor 13 Tahun 2003 tentang Ketenagakerjaan, dalam Pasal 185 tegas disebutkan bahwa pembayaran upah di bawah upah minimum merupakan tindak pidana kejahatan dan dikenakan sanksi pidana penjara paling singkat 1 (satu) tahun dan paling lama 4 (empat) tahun dan/atau denda paling sedikit Rp. 100.000.00,00 (seratus juta rupiah) dan paling banyak

28 Hasil wawancara dengan Ibu D, pekerja outsourcing PT. Mitra Utama Madani, pada tanggal 19 Juni 2020.

29 Hasil wawancara dengan Yugo, pekerja PT. Narendra Dewa Yoga yang bekerj sebagai security Universitas Bengkulu, pada tanggal 11 September 2013.

30 Hasil wawancara dengan Ibu F, pekerja outsourcing PT. Mitra Utama Madani, pada tanggal 19 Juni 2020. 
Rp. 400.000.000,00 (empat ratus juta rupah).

Selanjutnya penerapan waktu kerja lembur dan upah kerja lembur pada PT. Mitra Utama Madani juga tidak sesuai dengan peraturan perundangundangan yang berlaku.

Berdasarkan ketentuan Undangundang Nomor 13 Tahun 2003 tentang Ketenagakerjaan, dalam Pasal 78 ayat (2) disebutkan bahwa "waktu kerja lembur hanya dapat dilakukan paling banyak 3 (tiga) jam dalam 1(satu) hari dan 14 (empat belas) jam dalam 1 (satu) minggu". Padahal dalam praktiknya pekerja PT. Mitra Utama Madani yang bekerja dalam 1 (satu) hari melakukan kerja lembur sebanyak 4 (empat) jam. Ketika melakukan waktu kerja lembur pekerja PT. Mitra Utama Madani menerima upah kerja lembur.

Upah kerja lembur yang diberikan oleh PT. Mitra Utama Madani kepada pekerja outsourcing, sesuai dengan ketentuan Pasal 11 Peraturan Menteri Tenaga Kerja dan Transmigrasi Nomor KEP. 102/MEN/VI/2004 tentang Waktu Kerja Lembur dan Upah Kerja Lembur, dapat dihitung sebagai berikut:

- Gaji Pokok pekerja adalah sebesar Rp.930.000/bulan.

- Waktu kerja lembur yang dilakukan adalah 4 jam.

- Lembur jam pertama adalah: 1 jam $x$ $1,5 \times 1 / 173 \times$ upah sebulan

$=1$ jam $\times 1,5 \times 1 / 173 \times$ Rp.930.000 = Rp. 8.063,-

- Lembur jam berikutnya adalah: 2 jam $\times 2 \times 1 / 173 \times$ Upah Sebulan = 2 jam x 2 x 1/173 xRp.930.000 = Rp.21.502

- Total uang lembur yang didapat Herwanto dan Afriadi adalah: Rp.

8.063,- + Rp.21.502 = Rp.29.565

Berdasarkan perhitungan di atas, upah kerja lembur pekerja outsourcing PT. Mitra Utama Madani, telah sesuai dengan ketentuan Peraturan Menteri
Tenaga Kerja dan Transmigrasi Nomor KEP. 102/MEN/VI/2004 tentang Waktu Kerja Lembur dan Upah Kerja Lembur.

Berdasarkan hasil wawancara penelitian, PT. Mitra Utama Madani ada memberikan Tunjangan Hari Raya (THR). Meskipun PT. Mitra Utama Madani ada memberikan Tunjangan Hari Raya (THR) kepada pekerjanya, namun jumlah THR yang diberikan tidak sesuai dengan ketentuan peraturan perundang-undangan yang berlaku.

Berdasarkan ketentuan tersebut maka dapat disimpulkan bahwa PT. Mitra Utama Madani telah melanggar ketentuan peraturan perundangundangan yang berlaku yaitu Peraturan Menteri Tenaga Kerja RI No.Per 104/MEN/1994 tentang Tunjangan Hari Raya Keagamaan. Seharusnya pekerja outsourcing PT. Mitra Utama Madani berhak mendapatkan Tunjangan Hari Raya (THR) sebesar 1 (satu) bulan dari gaji pokoknya.

c. Perjanjian Kerja

Berdasarkan Hasil wawancara dengan

Bapak A Direktur Utama PT. Mitra Utama Madani diketahui bahwa antara PT. Mitra Utama Madani dengan pekerja outsourcing membuat perjanjian kerja secara tertulis.

Antara perusahaan dengan pekerja membuat perjanjian kerja. Biasanya setelah perusahaan memenangkan lelang, perusahaan akan memanggil pekerja dan menerangkan apa saja yang menjadi hak pekerja dan hak perusahaan sesuai dengan nilai kontrak dengan perusahaan pemberi kerja. $^{31}$

Saya sudah bekerja selama kurang lebih 4 (empat) tahun. Menegenai kontrak kerja, setiap satu tahun

31 Hasil wawancara dengan Bapak A, Direktur Utama PT. Mitra Utama Madani, pada tanggal 19 Juni 2020. 
sekali. ${ }^{32}$ Saya sudah bekerja selama kurang lebih 4 (empat) tahun. Selama bekerja menandatangani perjanjian kerja dengan PT. Mitra Utama Madani. ${ }^{33}$ Saya sudah bekerja selama 3 (tiga) tahun. Ketika mulai masuk bekerja ada perjian kerja secara tertulis dengan perusahaan. Awal masuk bekerja hanya disuruh mengikuti training selama 3 (tiga) bulan, sesudah itu apabila kinerja tidak baik maka siap diberhentikan. ${ }^{34}$

Dari hasil wawancara tersebut di atas diketahui bahwa antara PT. Mitra Utama Madani dengan pekerjanya ada membuat perjanjian kerja. Dalam Undang-undang No. 13 Tahun 2003 Pasal 50 menyebutkan bahwa: "Hubungan kerja terjadi karena adanya perjanjian kerja antara pengusaha dan pekerja/buruh".

Berdasarkan uraian di atas dapat disimpulkan bahwa PT. Mitra Utama Madani sebagai perusahaan penyedia jasa pekerja telah melanggar ketentuan peraturan perundang-undangan yang berlaku sebagaimana yang telah diatur dalam Undang-undang No 13 Tahun 2003 tentang Ketenagakerjaan Pasal 66 dan Peraturan Menteri Ketenagakerjaan No 11 Tahun 2019 Perubahan Kedua atas Peraturan Menteri Tenaga Kerja dan Transmigrasi No 19 Tahun 2012 tentang Syarat-syarat Penyerahan Sebagian Pelaksanaan Pekerjaan Kepada Perusahaan Lain, yaitu dalam Pasal 27.

Berdasarkan ketentuan Undang-undang No 13 Tahun 2003 tentang Ketenagakerjaan Pasal 66 ayat (4), dikarenakan adanya perjanjian kerja secara tertulis antara PT. Mitra Utama

32 Hasil wawancara dengan Bapak B, pekerja outsourcing PT. Mitra Utama Madani, pada tanggal 19 Juni 2020.

33 Hasil wawancara dengan Bapak C, pekerja outsourcing PT. Mitra Utama Madani, pada tanggal 19 Juni 2020.

34 Hasil wawancara dengan Ibu D, pekerja outsourcing PT. Mitra Utama Madani, pada tanggal 19 Juni 2020.
Madani dengan pekerja outsourcing maka demi hukum status hubungan kerja antara pekerja dan PT. Mitra Utama Madani beralih menjadi hubungan kerja antara pekerja dan perusahaan pemberi pekerjaan.

Perjanjian kerja bersama adalah suatu bentuk pengikatan antara pihak pengusaha dengan pihak pekerja dalam kaitannya untuk memberiakn hak dan kewajiban masing-masing pihak secara jelas. Kesepakatan para pihak menjadi dasar terbantuknya suatu perjanjian kerja bersama dengan demikian pada dasarnya kesepakatan yang dimaksud oleh pembuat undang-undang tidak terbatas secara bahasa (gramatikal) namun lebih ditekankan pada itikad baik masing-masing pihak, sehingga perjanjian yang dibuat tidak memiliki catatat kehendak dan benarbenar disepakati para pihak.

Bentuk-bentuk perjanjian yang lahir dari Buku III KUHPerdata pada umumnya merupakan bentuk perjanjian obligatoir yang artinya perjanjian tersebut menimbukan kewajiban-kewajiban bagi para pihak pembuatnya. Ketentuan mengikat dari perjanjian yang muncul seiring dengan asas kebebasan berkontrak yang memberikan kebebasan dan kemandiarian para pihak, pada situsiasi tertentu daya berlaku dibatasi. Dengan kata lain daya berlaku suatu kebebasan dan kemandirian tersebut dibatasi oleh itikad baik sebagaimana diatur dalam Pasal 1338 KUHPerdata. Dalam Pasal 1338 ayat (2) KUHPerdata jelas mengatur bahwa suatu perjanjian hanya bisa dibatalkan apabila kedua belah pihak menyepakatinya atau dengan kata lain dibatalkan secara bersama-sama maupun secara sepihak apabila cacat hukum. Cacat hukum ini telah diatur dalam Pasal 1321-1327 KUHPerdata. Proses perundingan pembuatan perjanjian kerja bersama membuat kekuatan masingmasing pihak tidak seimbang sehingga kekuatan runding yang berbeda tersebut membuat pekerja dalam kondisi yang kurang menguntungkan. Apabila perjanjian 
tersebut telah ditutup dengan kesepakatan para pihak dan akhirnya perjanjiian kerja bersama yang telah disepakati tersebut oleh sebagian besar pekerja di luar tim perunding tidak sesuai dengan dengan pernah yang dijanjikan sebelum proses perundingan terjadi, maka perjanjian kerja bersama apabila telah terjadi kesepakatan antara pihak-pihak yang membuatnya maka perjanjian tersebut telah mengikat pihak-pihak tersebut, dan tiada upaya yang dapat dilakukan untuk melakukan pembatalan.

\section{KESIMPULAN}

Berdasarkan hasil penelitian dan pembahasan di atas, maka penulis dapat mengambil kesimpulan, sebagai berikut:

1. Keberadaan perusahaan alih daya (outsourcing) dalam pekerja sistem kontrak, dalam hal hubungan kerja antara pekerja dan perusahaan outsourcing PT. Mitra Utama Madani berdasarkan Perjanjian Kerja Waktu Tertentu (PKWT), maka perjanjian kerja harus mensyaratkan adanya pengalihan perlindungan hak-hak bagi pekerja yang obyek kerjanya tetap ada, walaupun terjadi pergantian perusahaan yang melaksanakan sebagian pekerjaan borongan dari perusahaan lain atau perusahaan penyedia jasa pekerja.

2. Pemberian hak bagi pekerja terkait sistem kontrak berdasarkan Undangundang No. 13 Tahun 2003 tentang
Ketenagakerjaan di PT. Mitra Utama Madani masih ada pekerja outsourcing yang tidak terdaftar dalam Jamsostek, sehingga perlindungan hukum terhadap kesehatan dan keselamatan bagi pekerja outsourcing tersebut tidak terlaksana.

\section{SARAN}

1. Bagi para pihak yang akan membuat atau mengadakan suatu perjanjian/kontrak, hendaklah terlebih dahulu memahami dan mengerti mengenai dasar-dasar suatu perjanjian, terlebih lagi mengenai asas-asas yang berlaku dalam berkontrak sebelum menandatangani perjanjian/kontrak tersebut sehingga dapat terhindari hal-hal yang tidak diinginkan dan terlaksananya tujuan melakukan kontrak.

2. Pelaksanaan Undang-undang Ketenagakerjaan khususnya tenaga kerja outsourcing di Indonesia memerlukan pengawasan dan penindakan dari pihak pemerintah karena dalam pelaksanaannya perusahaan yang membuat perjanjian kerja dengan tenaga kerja outsourcing harus memenuhi hak-hak tenaga kerja sesuai dengan perjanjian kerja yang dibuat. Apabila hak-hak tenaga kerja tidak dipenuhi maka perusahaan perlu dikenakan sanksi hukum sesuai peraturan perundang-undangan yang berlaku.

\section{DAFTAR PUSTAKA}

\section{A. Buku:}

Adrian Sutedi, Hukum Perburuhan, Jakarta: Sinar Grafika, 2009.

Djoko Triyanto, Hubungan Kerja di Perusahaan Jasa Konstruksi, Bandung: Mandar Maju, 2004.

Djumialdji, Perjanjian Kerja, Jakarta: Bumi Aksara, Jakarta, 2005. 
Eko Richardus Indrajit dan Richardus Djokopranoto, Manajemen Outsourcing, Jakarta: Grasindo, 2003.

Gunarto Suhardi, Perlindungan Hukum Bagi Pekerja Kontrak, Yogyakarta: Atmajaya, 2006.

Hardijan Rusli, Hukum Ketenagakerjaan, Bogor: Ghalia Indonesia Cet. Ke-2, 2011.

Iftida Yasar, Outsourcing Tidak Akan Pernah Bisa Diapus, Jakarta: Pelita Pikir Indonesia, 2012.

, Sukses Implementasi Ousourcing, Jakarta: Ppm, 2008.

Lanny Ramli, Hukum Ketenagakerjaan, Surabaya: Airlangga University Press,.

Nuridin dan Tiyas Vika Widyastuti, Pelaksanaan Hak Normatif Tenaga Outsourcing di Perusahaan Penyedia Jasa Pekerja, Brebes: Diya Media Group, 2017.

R. Subekti, Aneka Perjanjian, Bandung: Alumni, 1989.

Sehat Damanik, Outsourcing dan Perjanjian Kerja, Jakarta: DSS Publishing, 2007.

Syamsuddin, Mohd. Syaufii, Norma Perlindungan Dalam Hubungan Industrial, Jakarta: Sarana Bhakti Persada, 2004.

\section{B. Jurnal Hukum}

Endeh Suhartini, Legal Perspective In Creating Employment Policies For Minimum Wage Payment Systems In The Company, Jurnal Vol. 1 Nomor 2, 2017.

Martin Roestamy dan R. Pepen Rustam Effendi, Perlindungan Hukum Bagi Pekerja Tambang Galian C Dalam Perspektif Pengupahan dan Kesejahteraan Pekerja di Wilayah Provinsi Jawa Barat, Jurnal Living Law, Vol. 10, No. 2, 2018.

T.N. Syamsah dan Ita Rosita, Perlindungan Hukum Terhadap Tenaga Kerja Dalam Perjanjian Kerja Waktu Tertentu Pada Perusahaan Garmen, Jurnal Living Law, Volume 8 Nomor 2, Oktober 2016.

\section{Peraturan Perundang-undangan}

Kitab Undang-undang Hukum Perdata.

Undang-undang Dasar Negara Republik Indonesia Tahun 1945.

Undang-undang Nomor 13 Tahun 2003 tentang Ketenagakerjaan.

Peraturan Menteri Ketenagakerjaan Nomor 11 Tahun 2019 Perubahan Kedua atas Peraturan Menteri Tenaga Kerja dan Transmigrasi Nomor 19 Tahun 2012 tentang Syarat-syarat Penyerahan Sebagian Pelaksanaan Pekerjaan Kepada Perusahaan Lain. 
Ujang Bahar, Endeh Suhartini, dan Dani Purwanto, Optimalisasi Perlindungan Hukum Tenaga Kerja Dalam Aspek Keselamatan Kerja Pada Proyek Konstruksi di Wilayah Bogor, Jurnal Ilmiah Living Law Volume 12 Nomor 1, Januari 2020.

\section{Internet}

Era Maranatha Sinaga, Outsourcing dan Perkembangan di Indonesia, blogspot.com, 2010.

Pan Mohamad Faiz, Tinjauan Yuridis terhadap Undang-undang Nomor 13 Tahun 2003 tentang Ketenagakerjaan, http://jurnalhukum.blogspot.com/2007/05/outsourcing-dantenaga-kerja.html., Diakses tanggal 20 Juni 2020. 